\title{
昡pubvet
}

https://doi.org/10.31533/pubvet.v14n4a543.1-4

\section{Avaliação espermática e histológica dos testículos e epidídimos de caninos naturalmente infectados por Brucella canis}

\author{
Fabiana Sperb Volkweis $^{1 *}{ }^{*}$, Hélio Blume ${ }^{2} \bullet$, Helvécio Leal Santos Júnior ${ }^{2} \bullet$, Andrea Maria \\ Lazzari $^{2} \odot$, Fernanda Mulinari ${ }^{2}$ \\ 1 Professora de Medicina Veterinária, centro universitário UNICEPLAC, Gama-DF, Brasil \\ 2 Professora de Medicina Veterinária, UPIS, Planaltina-DF \\ *Autor para correspondência, E-mail: fabisperb@hotmail.com
}

\begin{abstract}
Resumo. A brucelose canina é uma doença infectocontagiosa de carácter crônico, acarreta diretamente o trato reprodutivo do macho e da fêmea. Este estudo tem como objetivo avaliar e comparar os danos ocorridos por esta infecção em caninos machos. Foram selecionados 4 caninos positivos para brucelose canina, comprovado pelos testes de hemocultura, IDGA e PCR. Estes foram submetidos análise seminal, posterior orquideoctomia e avaliação histológica dos testículos. A análise seminal evidenciou alterações morfológicas compatíveis com a doença. Na histologia foi visualizado um infiltrado linfo-histiocitário multifocal intersticial moderado no epidídimo e nos testículos degeneração vacuolar.
\end{abstract}

Palavras chaves: brucelose canina, avaliação seminal, infertilidade

\section{Sperm and histological evaluation of testis and epididymis of canine} naturally infected by Brucella canis

\begin{abstract}
Canine brucellosis is a chronic infectious disease that directly affects the male and female reproductive tract. This study aims to evaluate and compare the damage caused by this infection in male canines. Four canines positive for canine brucellosis were selected, confirmed by blood culture, IDGA and PCR tests. They were submitted to seminal analysis, posterior orchiectomy and histological evaluation of the testicles. Seminal analysis showed morphological changes compatible with the disease. On histology a moderate interstitial multifocal lymphohistiocytic infiltrate was visualized in the epididymis and in the teste's vacuolar degeneration.
\end{abstract}

Keywords: canine brucellosis, seminal evaluation, infertility

\section{Evaluación espermática e histológica de testículos y epidídimos de caninos infectados naturalmente por Brucella canis}

Resumen. La brucelosis canina es una enfermedad infecciosa crónica que afecta directamente el aparato reproductor masculino y femenino. Este estudio tiene como objetivo evaluar y comparar el daño causado por esta infección en los caninos machos. Se seleccionaron cuatro caninos positivos para brucelosis canina, comprobados por hemocultivo, IDGA y pruebas de PCR. Fueron sometidos a análisis seminal, posterior orquiectomía y evaluación histológica de los testículos. El análisis seminal mostró cambios morfológicos compatibles con la enfermedad. En la histología se visualizó un 
infiltrado linfohistiocítico multifocal intersticial moderado en el epidídimo y en los testículos degeneración vacuolar.

Palabras claves: brucelosis canina, evaluación seminal, infertilidad

\section{Introdução}

A Brucelose canina é uma enfermidade infecciosa cujos principais sintomas clínicos são abortos em fêmeas no terço final da gestação, filhotes fracos que sobrevivem pouco tempo ou natimortos. Nos machos, a infecção causa epididimite unilateral ou bilateral, aumento ou atrofia testicular, inflamação da próstata e esterilidade (Boeri et al., 2008). O sêmen de machos infectados contém grande número de espermatozoides anormais e de células inflamatórias, principalmente após três meses de infecção. Machos cronicamente infectados podem não produzir mais espermatozoides ou reduzir número de espermatozoides imaturos. A bactéria fica alojada na glândula prostática durante muitos meses, ela é disseminada pelo líquido seminal e urina (Shin \& Carmichael, 1999). A brucelose canina tem impacto direto na reprodução canina e na saúde pública a nível mundial. Gera perdas econômicas em canis comerciais, devido à infertilidade e abortos, e apresenta risco de transmissão zoonótica aos trabalhadores e aos proprietários dos cães (Castro et al., 2010; Echeverri et al., 2009).

Para diagnóstico definitivo deve-se considerar o histórico clínico e a anamnese em conjunto com a sorologia e o exame bacteriológico. Um diagnóstico diferencial deve ser ponderado para excluir causas infecciosas de infertilidade em caninos como agentes virais (herpes vírus), parasitário (Neospora caninum, Toxoplasma gondii), e de etiologia bacteriana (Mycoplasma, Ureaplasma, E.coli, Streptomyces e B. Canis) (Keid \& Vasconcellos, 2001). A associação de métodos diretos e indiretos é essencial para um diagnóstico definitivo da brucelose canina. Testes sorológicos, cultura de sangue associados com PCR são ferramentas importantes para diagnóstico da brucelose canina (Boeri et al., $\underline{2018}$.

O objetivo deste trabalho foi relatar alterações seminais de cães com brucelose canina, para o fim de documentar as alterações desta enfermidade. E fazer um estudo comparativo com as lesões histológicas previamente encontradas.

\section{Materiais e métodos}

Foram selecionados 4 caninos testados para brucelose canina, um canino Golden Retrivier, macho de 6 anos, domiciliado, IDGA positivo e PCR positivo. Um Pit bull, macho, 8 meses, e um Pug, 8 meses os dois provenientes de canil comercial, IDGA, PCR e hemocultura positiva e outro Pit bull, de 8 anos também de canil comercial positivo na hemocultura, PCR e IDGA. Os cães apresentavam sinais clínicos variados, assim como, lesão testicular, falhas reprodutivas, históricos de aborto. Os cães foram submetidos à orquideoctomia. Antes do procedimento cirúrgico foi coletado sêmen por manipulação digital para avaliação espermática e após a castração os testículos foram acondicionados em frasco de vidro com formol a $10 \%$ e encaminhados para o setor de patologia da UPIS. A realização do IDGA foi obtida com o soro dos caninos e realizada utilizando KIT comercial produzido pelo Instituto de Tecnologia do Paraná (TECPAR). A extração de DNA segundo Vieira (2004) e realização das PCRs. $\mathrm{O}$ sangue total $(2 \mathrm{~mL})$ foi semeado em caldo fosfato triptose e incubado em estufa bacteriológica a $37^{\circ}$ $\mathrm{C}$ durante trinta dias. A cada 5 dias, 20 microlitros do caldo foi repicado em placas de ágar sangue triptose e incubadas a $37^{\circ} \mathrm{C}$ por 7 dias. A identificação bacteriana das colônias foi baseada nas características morfológicas e bioquímicas (Shin \& Carmichael, 1999).

Foi realizada avaliação histológica do epidídimo e dos testículos, dos quatro caninos infectados com Brucella canis.

\section{Resultados e discussão}

Os quatro cães apresentaram soro positividade no teste sorológico. Somente dois cães obtiveram o exame da hemocultura positivo, entretanto, todos cães soropositivos foram confirmados no teste da PCR (Tabela 1). Essa diferença de resultados entre hemocultura e os demais testes realizados podem ser explicados pelo fato da bacteremia, na brucelose canina, embora possa ter carácter prolongado, possa ser intermitente e eventualmente diminuir em infecções crônicas (Jhonson \& Walker, 1992). 
Em exame histopatológico Megid et al. (2002) revelou infiltrado neutrófilo e necrose de coagulação em testículo e reação granulomatosa com infiltrado mononuclear. No presente estudo foi evidenciado discreta degeneração vacuolar do epitélio de túbulos associado a fibrose intersticial (Figura 1).

Tabela 1. Resultados de exames realizados para detecção de Brucella canis.

\begin{tabular}{lccccc}
\hline Canino & Raça & Idade & IDGA & Hemocultura & PCR \\
\hline C1 & Pug & 8 meses & + & + & + \\
C2 & Pit bull & 8 anos & + & - & + \\
C3 & Pit bull & 8 meses & + & + & + \\
C4 & Golden Retrivier & 6 anos & + & - & + \\
\hline
\end{tabular}

No epidídimo foi visualizado um infiltrado linfoplasmocitário moderado a acentuado extenso (Figura 2), observou-se também áreas com o epitélio vacuolizado intercalando com os túbulos com epitélio notou-se disposição de tecido conjuntivo fibroso moderado peri-tubular, caracterizando a reação inflamatória compatível com B. canis.

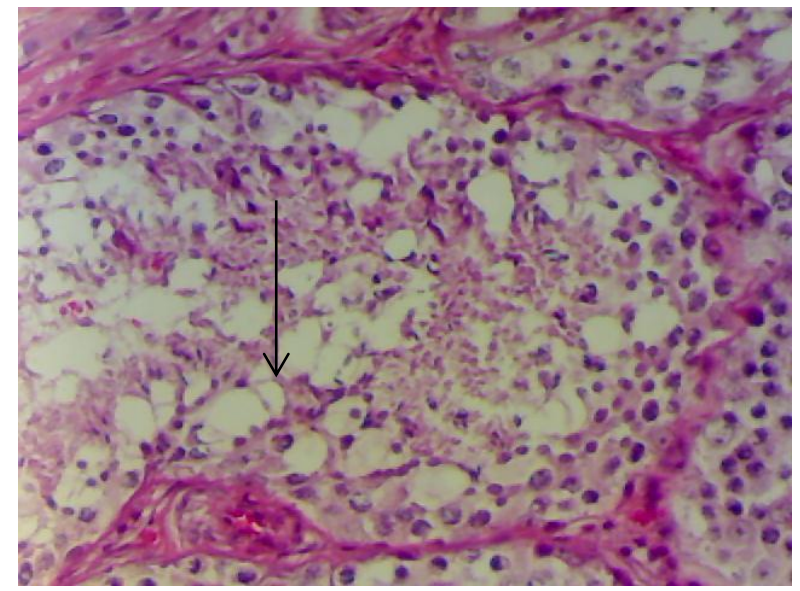

Figura 1. Fotomicrografia:Testículo:Túbulo germinativo (seta): Vacuolização e atrofia epitélio germinativo (seta). HeE.40x.

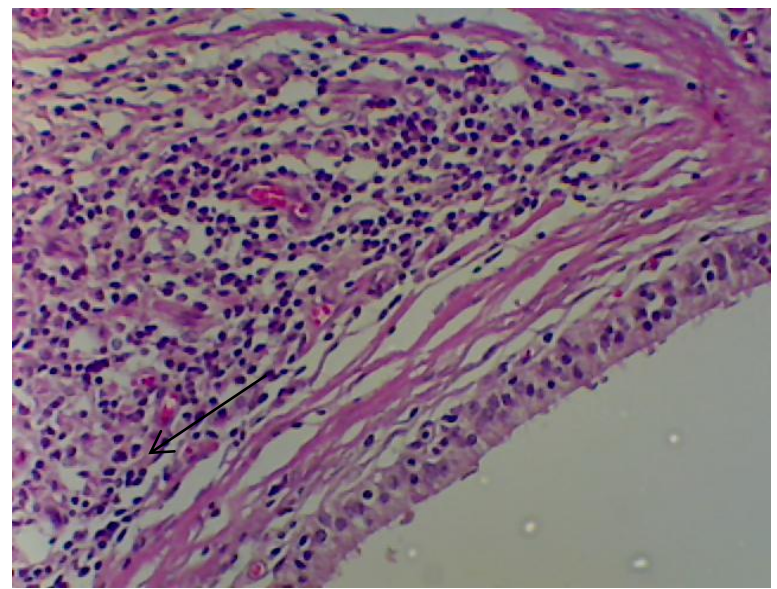

Figura 2. Fotomicrografia: Epidídimo: Infiltrado do linfoplasmocitário moderado a acentuado extenso (seta). HeE. 40x.

As alterações morfológicas dos espermatozoides mais encontradas foram cabeça dobrada, cabeça fortemente dobrada e cauda enrolada (Tabela 2). O sêmen de machos infectados geralmente contém grande número de espermatozoides anormais e células inflamatórias, especialmente nos 3 primeiros meses após a infecção. Caninos cronicamente infectados podem ter diminuição nos números de espermatozoides (Serikawa et al., 1989; Shin \& Carmichael, 1999). Este fato, justifica a azospermia do canino A3, por provável infecção crônica de brucelose canina.

Tabela 2. Análise de espermograma de acordo com deformidades dos espermatozóides.

\begin{tabular}{lcccc}
\hline Anormalidades & A1 & A2 & A3 & A4 \\
\hline Cabeça dobrada & 13 & - & - & 4 \\
Cabeça fortemente dobrada & 8 & 3 & - & 2 \\
Cabeça oblíqua & 2 & - & - & \\
Cabeça pequena & 1 & - & - & 4 \\
Cauda sem cabeça & 2 & - & - & 3 \\
Cauda enrolada & 8 & 1 & - & 4 \\
Cabeça solta & - & - & - & \\
\hline
\end{tabular}

*- azospermia

As alterações seminais observadas corroboram com os citados por George et al. (1979), como cabeças enroladas e desprendimentos de cabeça. Plummer et al. (1987) em análise de sêmen de canino 
da raça Lhasa Apso, infectado com B. canis, com histórico de infertilidade, sua principal alteração espermática foi de gota citoplasmática proximal não encontrada no presente relato.

\section{Conclusão}

Diante dos resultados deste trabalho podemos concluir que a brucelose canina, causa danos ao sistema reprodutor do canino, levando uma diminuição da sua capacidade reprodutiva. Deve ser considerado o fato desta enfermidade ser uma zoonose de fácil disseminação e que gera grandes prejuízos a canis comerciais, tornando-se necessário instituir medidas de controle e erradicação desta doença.

\section{Referências bibliográficas}

Boeri, E., Escobar, G. I., Ayala, S. M., Sosa-Estani, S., \& Lucero, N. E. (2008). Brucelosis canina en perros de la ciudad de Buenos Aires. Medicina, 68(4), 291-297.

Boeri, E. J., Wanke, M. M., Madariaga, M. J., Teijeiro, M. L., Elena, S. A., \& Trangoni, M. D. (2018). Comparison of four polymerase chain reaction assays for the detection of Brucella spp. in clinical samples from dogs. Veterinary World, 11(2), 201-208.

Castro, J. R., Salaberry, S. R. S., Ribeiro, V. C., Souza, M. A., \& Lima-Ribeiro, A. M. C. (2010). Brucelose canina-Revisão de literatura. PUBVET, 4(41), Art-981.

Echeverri, C. A. G., Ruiz Cortés, Z. T., \& Ángel, M. O. (2009). Brucella canis en Medellín (Colombia), un problema actual. Revista U.D. C. A. Actualidad \& Divulgação Científica, 12(1), 51-57.

George, L. W., LW, G., \& LE, C. (1979). Semen examination in dogs with canine brucellosis. American Journal Veternary Research, 40(11), 274-281.

Keid, L. B., \& Vasconcellos, S. A. (2001). Diagnóstico da brucelose canina por Brucella canis. Corelação entre exames clínicos e laboratoriais: imunodifusão em gel de ágar, imunodifusão em gel de ágar com emprego de 2-mercaptoetanol, cultivo e reação em cadeia pela polimerase. Universidade de São Paulo.

Megid, J., Ribeiro, M. G., Moraes, C. C. G., Nardi Júnior, G., Paes, A. C., Prestes, N. C., \& Listoni, F. J. P. (2002). Brucelose Canina-Relato De Caso. Arquivos Do Instituto Biológico, 69(4), 103-106.

Plummer, J. M., Watson, P. F., \& Allen, W. E. (1987). A spermatozoal midpiece abnormality associated with infertility in a Llasa Apso dog. Journal of Small Animal Practice, 28(8), 743-751.

Serikawa, T., Iwaki, S., Mori, M., Muraguchi, T., \& Yamada, J. (1989). Purification of a Brucella canis cell wall antigen by using immunosorbent columns and use of the antigen in enzyme-linked immunosorbent assay for specific diagnosis of canine brucellosis. Journal of Cinical Microbiology, 27(5), 837-842.

Shin, S., \& Carmichael, L. E. (1999). Canine Brucellosis Caused by Brucella Canis (23 Nov 1999). International Veterinary Information Service.

Vieira, N. do R. (2004). Desenvolvimento de uma reação em cadeia pela Polimerase (PCR) para detecção de Brucella spp. em amostras de sangue de cães naturalmente infectados. Universidade de São Paulo.

Johnson, C. A \& Walker, R. D. (1992) Clinica signs and diagnosis of Brucella canis infection. Compendium on Continuing Education for the Practicing Veterinarian:Small Animal. 14, 763-772.

Recebido: 8 de novembro, 2019.

Aprovado: 7 de dezembro, 2019.

Publicado: 14 maio 2020.

Licenciamento: Este artigo é publicado na modalidade Acesso Aberto sob a licença Creative Commons Atribuição 4.0 (CC-BY 4.0), a qual permite uso irrestrito, distribuição, reprodução em qualquer meio, desde que o autor e a fonte sejam devidamente creditados. 